\title{
Wildfire events at the Triassic-Jurassic boundary of the Tabas Basin, Central Iran
}

\author{
Majid Alipour $^{1}\left(\mathbb{D} \cdot\right.$ Bahram Alizadeh $^{1} \cdot$ AmirAbbas Jahangard $^{1} \cdot$ AhmadReza GandomiSani $^{2}$
}

Received: 19 October 2020/Revised: 17 January 2021/Accepted: 24 April 2021/Published online: 21 May 2021

(C) The Author(s) 2021

\begin{abstract}
This paper presents organic geochemical evidence pointing to the occurrence of wildfire events at the TriassicJurassic boundary in Central Iran. The studied outcrop section (the Kamarmacheh Kuh section) is comprised of the Upper Triassic Nayband Formation which passes conformably into the Lower Jurassic Ab-e-Haji Formation with no sharp boundary. Organic petrographical studies reveal a higher concentration of semi-fusinite macerals and microscopic charcoal at the boundary between studied formations. This observation can be an evidence for widespread wildfire events at the Triassic-Jurassic boundary of the studied area. Following these fires, vast areas of land were exposed for erosion and large volumes of clastic sediments were provided due to increased run-off. This agrees well with previous sedimentological and stratigraphical studies suggesting a major change in the depositional conditions from marine to non-marine at the TriassicJurassic boundary of the Tabas Basin. These findings can have important implications about paleo-depositional settings of the studied formations and the nature of the associated organic matter.
\end{abstract}

Keywords Wildfire events · Triassic-Jurassic boundary · Nayband and Ab-e-Haji formations · Tabas Basin · Central Iran

\section{Introduction}

Wildfires across Triassic-Jurassic (T-J) boundary have been reported from various parts of the world including Turkey (Korkmaz and Gülbay 2007), Poland (Marynowski and Simoneit 2009), USA (Jones et al. 2002), and Australia

Majid Alipour

alipour@scu.ac.ir

Bahram Alizadeh

alizdeh@scu.ac.ir

AmirAbbas Jahangard

jahangard.amir@gmail.com

AhmadReza GandomiSani

gandomisani@gmail.com

1 Department of Petroleum Geology and Sedimentary Basins, Faculty of Earth Sciences, Shahid Chamran University of Ahvaz, Ahvaz, Iran

2 Exploration Directorate (ED), National Iranian Oil Company, Tehran, Iran
(Jiang et al. 1998). This paper, is the first report of paleowildfire events across the T-J boundary of the Tabas Basin (Central Iran). The stratigraphic properties and depositional environments of sedimentary units around the T-J boundary have been previously studied in Central Iran (SeyedEmami 2003; Seyed-Emami et al. 2004; Shadan and Hosseini-Barzi 2013; Wilmsen et al. 2009a). Based on these studies, the Central Iranian basin was detached from the Gondwana during the Late Permian-Early Triassic and moved northward to collide with Eurasia in the Late Triassic. This collision event had a major impact on sedimentary evolution of the T-J boundary in Central Iran (Seyed-Emami et al. 2004; Wilmsen et al. 2009b). The platform carbonated of Lower and Middle Triassic were followed by the thick post-collisional sediments during Upper Triassic-Lower Jurassic (i.e. the Shemshak Group) (Seyed-Emami 2003; Wilmsen et al. 2009a). During the early phases of the orogenic movements, the Upper Triassic Nayband Formation was deposited under marine conditions, which were gradually replaced by the non- 


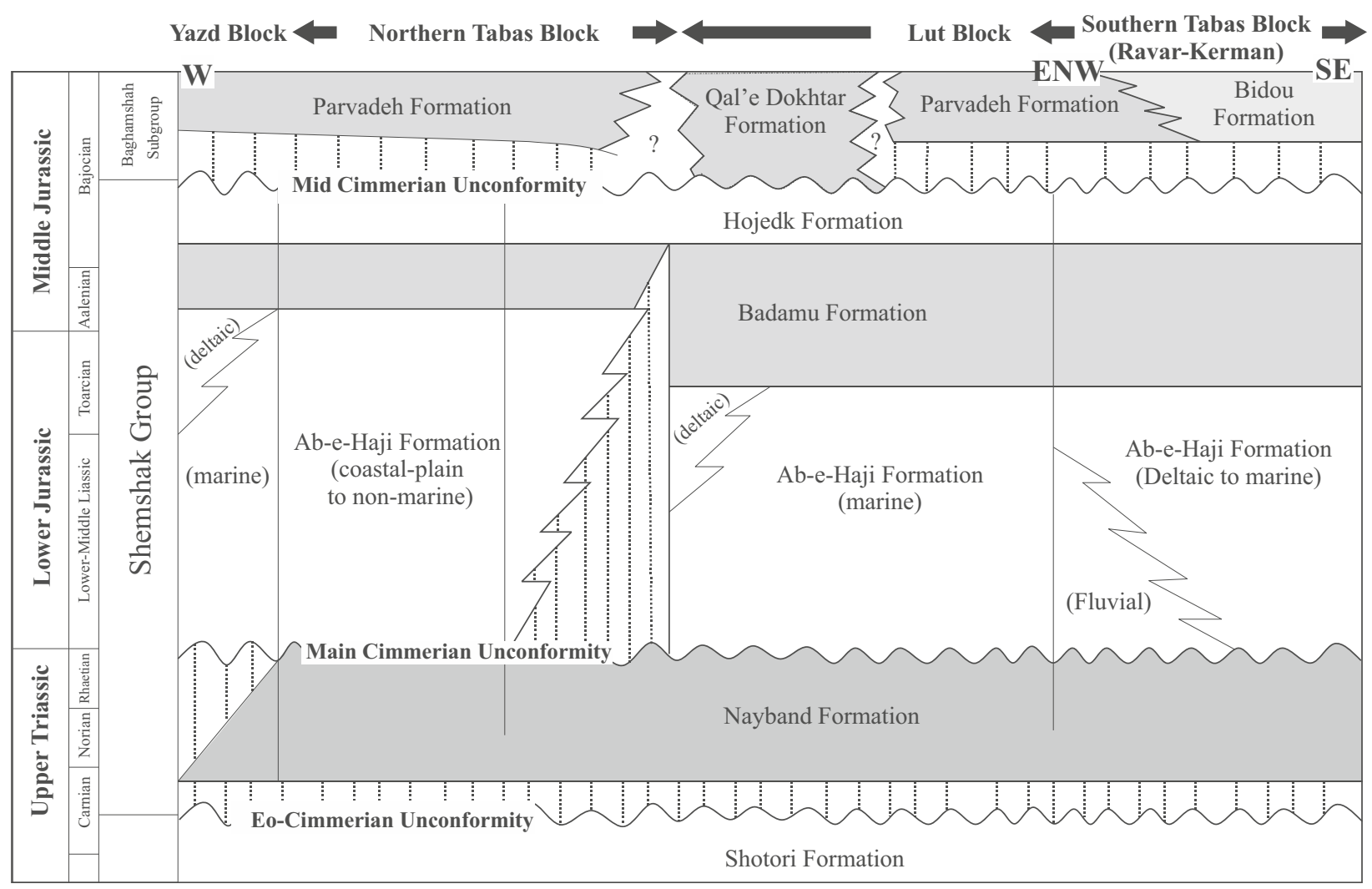

Fig. 1 Generalized stratigraphic column of the Central Iran basin during the Triassic-Jurassic boundary. (Modified after Salehi et al. 2014; Seyed-Emami 2003; Wilmsen et al. 2009a)

marine Ab-e-Haji Formation (Wilmsen et al. 2009a) (Fig. 1). The organic geochemistry and paleo-depositional environments of these sediments are recently addressed in the literature (Alizadeh et al. 2010, 2011; Zamansani et al. 2019).
A thick sedimentary package, consisting of the Nayband and Ab-e-Haji formations (approximately $1600 \mathrm{~m}$ ), is available at Kamarmacheh Kuh section located about $50 \mathrm{~km} \mathrm{SW}$ of the Tabas city (Fig. 2). Unlike many other places in Iran, sedimentation across the T-J boundary is

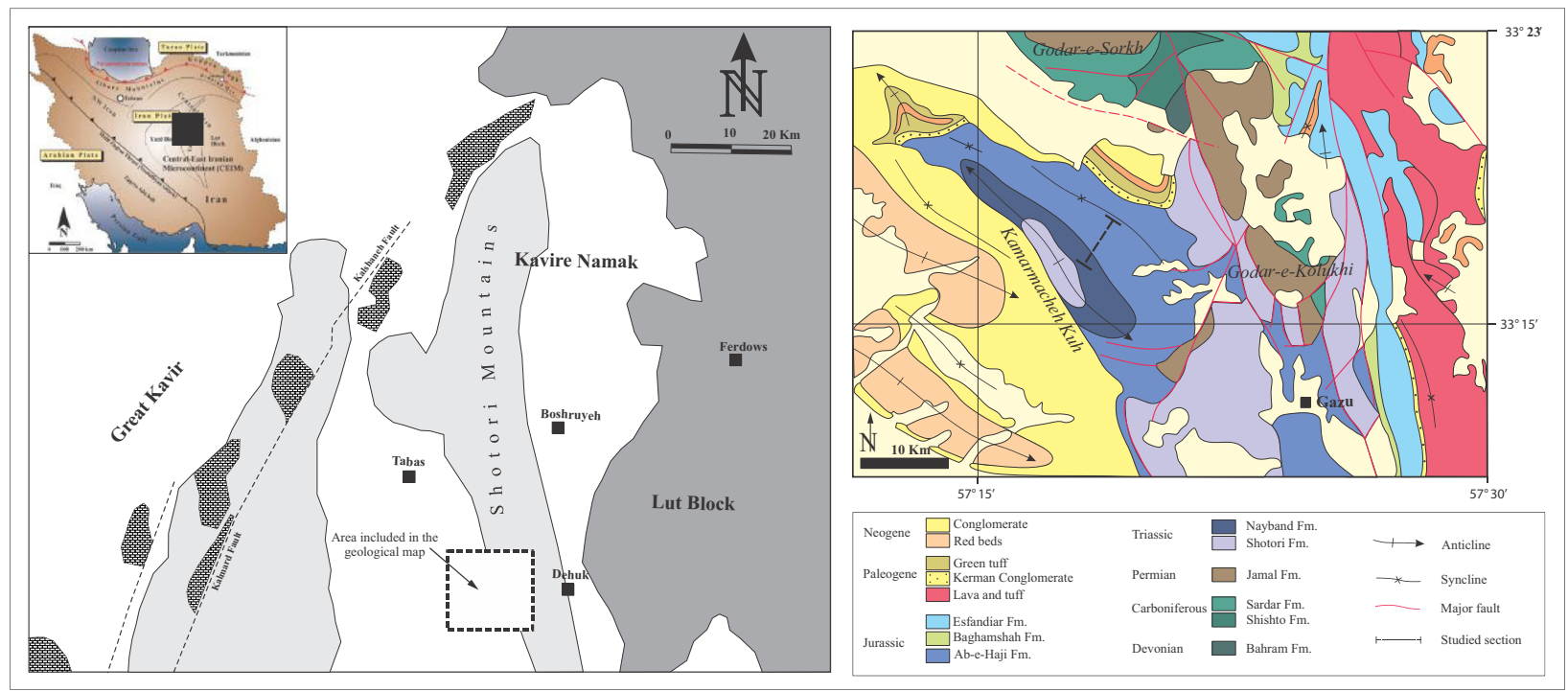

Fig. 2 Generalized geological map of the studied area indicating the location of the Kamarmacheh Kuh section. (Modified after Wilmsen et al. (2009a) and unpublished geological map of Boshruyeh 1:250000) 
Table 1 Rock-Eval pyrolysis data for samples from Nayband and Ab-e-Haji formations

\begin{tabular}{|c|c|c|c|c|c|c|c|c|c|}
\hline \multirow[t]{2}{*}{ Sample } & \multicolumn{5}{|c|}{ Rock-Eval dataz } & \multicolumn{4}{|c|}{ Calculated ratios } \\
\hline & $\begin{array}{l}\text { TOC } \\
(\mathrm{wt} \%)\end{array}$ & $\begin{array}{l}\mathrm{S}_{1}(\mathrm{mg} \\
\mathrm{HC} / \mathrm{g} \text { rock })\end{array}$ & $\begin{array}{l}\mathrm{S}_{2}(\mathrm{mg} \\
\mathrm{HC} / \mathrm{g} \text { rock })\end{array}$ & $\begin{array}{l}\mathrm{S}_{3}(\mathrm{mg} \\
\left.\mathrm{CO}_{2} / \mathrm{g} \text { rock }\right)\end{array}$ & $T_{\max }\left({ }^{\circ} \mathrm{C}\right)$ & $\begin{array}{l}\text { HI (mg } \\
\text { HC/g TOC) }\end{array}$ & $\begin{array}{l}\mathrm{OI}(\mathrm{mg} \\
\mathrm{CO}_{2} / \mathrm{g} \text { TOC) }\end{array}$ & $\mathrm{S}_{2} / \mathrm{S}_{3}$ & PI \\
\hline \multicolumn{10}{|c|}{ Ab-e-Haji formation } \\
\hline A-41 & 0.46 & 0.05 & 0.21 & 0.13 & 380 & 45.65 & 28.26 & 1.62 & 0.19 \\
\hline A-40 & 0.47 & 0.03 & 0.15 & 0.19 & 385 & 31.91 & 40.43 & 0.79 & 0.17 \\
\hline A-39 & 0.55 & 0.03 & 0.13 & 0.25 & 484 & 23.64 & 45.45 & 0.52 & 0.19 \\
\hline A-38 & 0.51 & 0.04 & 0.20 & 0.23 & 610 & 39.22 & 45.10 & 0.87 & 0.17 \\
\hline A-37 & 0.59 & 0.03 & 0.43 & 0.28 & 612 & 72.88 & 47.46 & 1.54 & 0.07 \\
\hline A-36 & 0.75 & 0.07 & 0.37 & 0.16 & 444 & 49.33 & 21.33 & 2.31 & 0.16 \\
\hline A-35 & 0.31 & 0.03 & 0.20 & 0.44 & 381 & 64.52 & 141.94 & 0.45 & 0.13 \\
\hline A-34 & 0.32 & 0.03 & 0.07 & 0.10 & 472 & 21.88 & 31.25 & 0.70 & 0.30 \\
\hline A-33 & 0.69 & 0.14 & 0.47 & 0.09 & 612 & 68.12 & 13.04 & 5.22 & 0.23 \\
\hline A-32 & 0.28 & 0.03 & 0.09 & 0.13 & 389 & 32.14 & 46.43 & 0.69 & 0.25 \\
\hline A-31 & 0.32 & 0.05 & 0.29 & 0.15 & 612 & 90.63 & 46.88 & 1.93 & 0.15 \\
\hline A-30 & 0.56 & 0.01 & 0.15 & 0.24 & 461 & 26.79 & 42.86 & 0.63 & 0.06 \\
\hline A-29 & 0.86 & 0.02 & 0.07 & 0.29 & 601 & 8.14 & 33.72 & 0.24 & 0.22 \\
\hline A-28 & 0.59 & 0.03 & 0.22 & 0.14 & 473 & 37.29 & 23.73 & 1.57 & 0.12 \\
\hline A-27 & 0.57 & 0.03 & 0.30 & 0.26 & 383 & 52.63 & 45.61 & 1.15 & 0.09 \\
\hline A-26 & 0.26 & 0.01 & 0.02 & 0.24 & 604 & 7.69 & 92.31 & 0.08 & 0.33 \\
\hline A-25 & 0.57 & 0.01 & 0.03 & 0.31 & 531 & 5.26 & 54.39 & 0.10 & 0.25 \\
\hline A-24 & 0.19 & 0.04 & 0.04 & 0.10 & 288 & 21.05 & 52.63 & 0.40 & 0.50 \\
\hline A-23 & 0.20 & 0.02 & 0.53 & 0.08 & 612 & 26.50 & 40.00 & 6.63 & 0.04 \\
\hline A-22 & 0.69 & 0.02 & 0.12 & 0.30 & 512 & 17.39 & 43.48 & 0.40 & 0.14 \\
\hline A-21 & 0.58 & 0.03 & 0.18 & 0.13 & 513 & 31.03 & 22.41 & 1.38 & 0.14 \\
\hline A-20 & 0.94 & 0.02 & 0.23 & 0.27 & 517 & 24.47 & 28.72 & 0.85 & 0.08 \\
\hline A-19 & 0.61 & 0.04 & 0.08 & 11 & 605 & 13.11 & 1803.28 & 0.01 & 0.33 \\
\hline A-18 & 0.52 & 0.03 & 0.13 & 0.22 & 490 & 25.00 & 42.31 & 0.59 & 0.19 \\
\hline A-17 & 1.92 & 0.14 & 0.61 & 0.45 & 461 & 31.77 & 23.44 & 1.36 & 0.19 \\
\hline A-16 & 0.91 & 0.04 & 0.25 & 0.25 & 506 & 27.47 & 27.47 & 1.00 & 0.14 \\
\hline A-15 & 0.68 & 0.02 & 0.26 & 0.12 & 508 & 38.24 & 17.65 & 2.17 & 0.07 \\
\hline \multicolumn{10}{|c|}{ Nayband formation } \\
\hline $\mathrm{N}-14$ & 0.67 & 0.02 & 0.13 & 0.31 & 514 & 19.40 & 46.27 & 0.42 & 0.13 \\
\hline $\mathrm{N}-13$ & 0.91 & 0.03 & 0.29 & 0.15 & 489 & 31.87 & 16.48 & 1.93 & 0.09 \\
\hline $\mathrm{N}-12$ & 1.27 & 0.02 & 0.32 & 0.35 & 526 & 25.20 & 27.56 & 0.91 & 0.06 \\
\hline $\mathrm{N}-11$ & 0.42 & 0.01 & 0.01 & 0.18 & 454 & 2.38 & 42.86 & 0.06 & 0.50 \\
\hline $\mathrm{N}-10$ & 0.56 & 0.01 & 0.18 & 0.46 & 496 & 32.14 & 82.14 & 0.39 & 0.05 \\
\hline N-9 & 0.59 & 0.01 & 0.05 & 0.40 & 518 & 8.47 & 67.80 & 0.13 & 0.17 \\
\hline $\mathrm{N}-8$ & 0.52 & 0.01 & 0.02 & 0.40 & 515 & 3.85 & 76.92 & 0.05 & 0.33 \\
\hline $\mathrm{N}-7$ & 0.58 & 0.01 & 0.40 & 0.30 & 523 & 68.97 & 51.72 & 1.33 & 0.02 \\
\hline N-6 & 0.57 & 0.01 & 0.02 & 0.49 & 525 & 3.51 & 85.96 & 0.04 & 0.33 \\
\hline N-5 & 0.62 & 0.01 & 0.08 & 0.34 & 609 & 12.90 & 54.84 & 0.24 & 0.11 \\
\hline N-4 & 0.57 & 0.01 & 0.04 & 0.31 & 520 & 7.02 & 54.39 & 0.13 & 0.20 \\
\hline $\mathrm{N}-3$ & 0.51 & 0.01 & 0.03 & 0.39 & 516 & 5.88 & 76.47 & 0.08 & 0.25 \\
\hline $\mathrm{N}-2$ & 0.47 & 0.01 & 0.02 & 0.31 & 522 & 4.26 & 65.96 & 0.06 & 0.33 \\
\hline N-1 & 0.54 & 0.01 & 0.02 & 0.42 & 521 & 3.70 & 77.78 & 0.05 & 0.33 \\
\hline
\end{tabular}

Samples selected for organic petrographic analyses are highlighted in boldface 

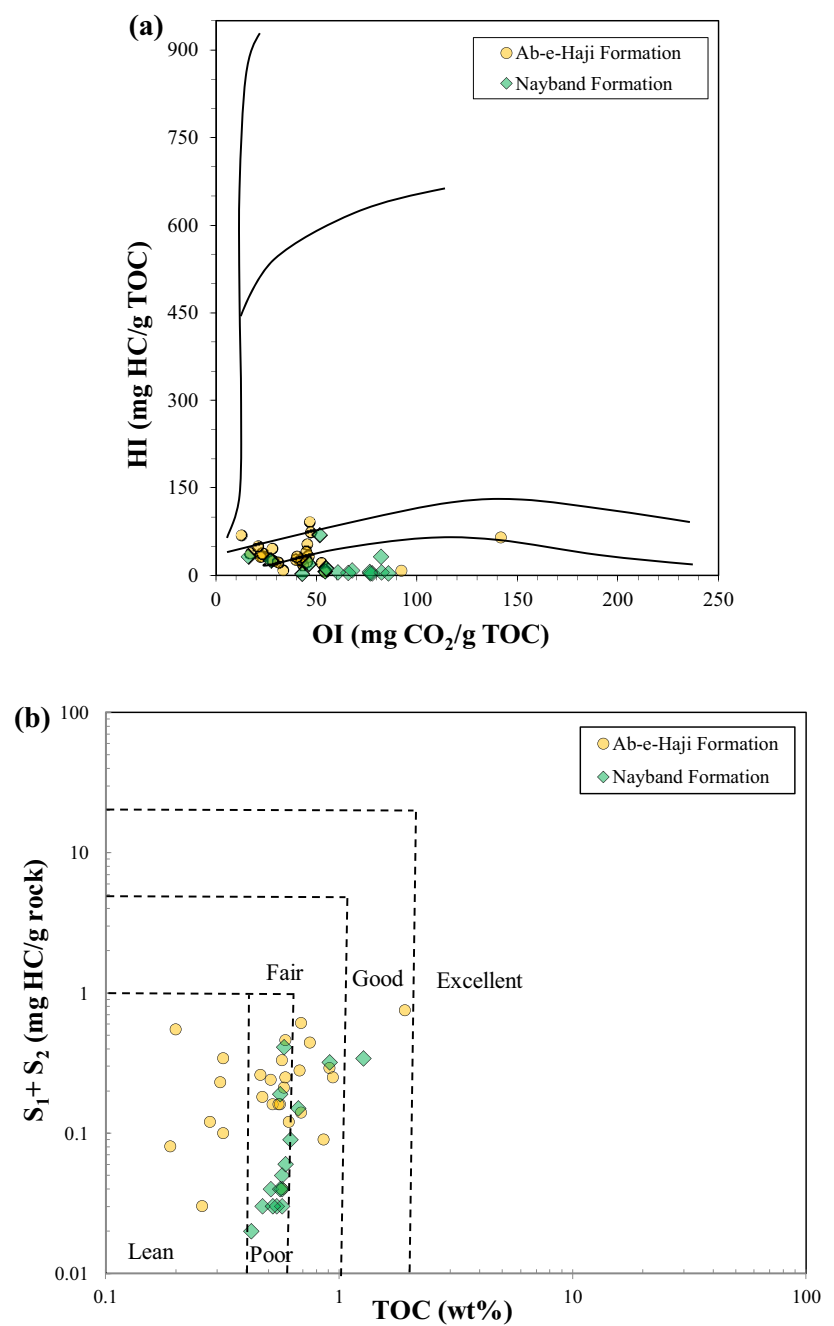

Fig. 3 Plots of HI versus OI a and generation potential $\left(S_{1}+S_{2}\right)$ versus TOC $\mathbf{b}$ for the studied samples from the Kamarmacheh Kuh section

continuous at this location. The fine-grained marine siliciclastic and carbonate sediments of the Nayband Formation contain abundant fossils and pass into the overlying fluvial siliciclastic sediments of the Ab-e-Haji Formation conformably. These sediments are systematically sampled in this study and were subjected to detailed organic geochemical and petrographical analyses. Our results provided evidence for widespread wildfire events across T-J boundary in the studied sediments and helped better understand their paleo-depositional conditions.

\section{Geological settings}

The Mesozoic stratigraphy of Central Iran has largely been controlled by its tectonic history (Wilmsen et al. 2009b). During most of the Paleozoic the Central Iranian micro- continent was part of the Gondwana (Berberian and King 1981; Stöcklin 1974). However, it became detached from Gondwana during the Permian and collided with Eurasia during the Late Triassic (Stöcklin 1974). This collision resulted in the Eo-Cimmerian event (Wilmsen et al. 2009b) (Figs. 2, 9a). Due to this event, the Middle Triassic platform carbonates (i.e. the Shotori Formation) were uplifted, eroded, and unconformably overlain by a large siliciclastic sequence (i.e. the Norian-Bajocian Shemshak Group) (Fürsich et al. 2009; Stöcklin et al. 1965). Consequently, the lower boundary of the Shemshak Group in Central Iran is marked by the Eo-Cimmerian unconformity (Fig. 2).

Another important event related to the main-uplift phase of the Cimmerian Orogeny occurred at the T-J boundary (Fig. 2). This event (i.e. the Main Cimmerian event) signifies the ending of marine sedimentation (i.e. Nayband Formation) and establishment of non-marine/fluvial depositional regimes (i.e. Ab-e-Haji Formation) (Wilmsen et al. 2009a). Although the exact reason for this unconformity is not clear yet, some authors have related it to the slab breakoff of the Paleo-Tethys oceanic crust (Wilmsen et al. 2009b) (Fig. 9b). Nevertheless, the subduction initiation of the Neo-Tethyan oceanic floor during the latest TriassicEarly Jurassic time (Hassanzadeh and Wernicke 2016) may also have played some roles during the Main Cimmerian event (Fig. 9b).

The Mid-Cimmerian unconformity defines the upper boundary of the Shemshak Group in Central Iran (Fig. 2). This event represents a brief pulse of uplift during the midBajocian and has been ascribed to the break-up of South Caspian Basin (Wilmsen et al. 2009b).

Accordingly, the Mesozoic stratigraphy of the Central Iran is characterized by subduction processes and extensional tectonic regimes over much of the area (SeyedEmami 2003). This is particularly the case with the Lower Jurassic sediments which are characterized by widespread presence of basic volcanic and volcano-clastic units (Fürsich et al. 2005b; Seyed-Emami 2003).

\section{Analytical methods}

A total of 41 samples were collected from a surface outcrop of the Nayband and Ab-e-Haji formations in the Kamarmacheh Kuh section (Fig. 1 and Table 1). Special care was taken in collecting samples as to pick them from nonweathered fresh parts of the rocks.

These samples were first analyzed by Rock-Eval pyrolysis instrument for geochemical evaluation. Prior to analysis, the samples were grounded in the laboratory and stored in the oven for $24 \mathrm{~h}$ under a constant temperature of $40{ }^{\circ} \mathrm{C}$ to eliminate moisture. Approximately $70 \mathrm{mg}$ 


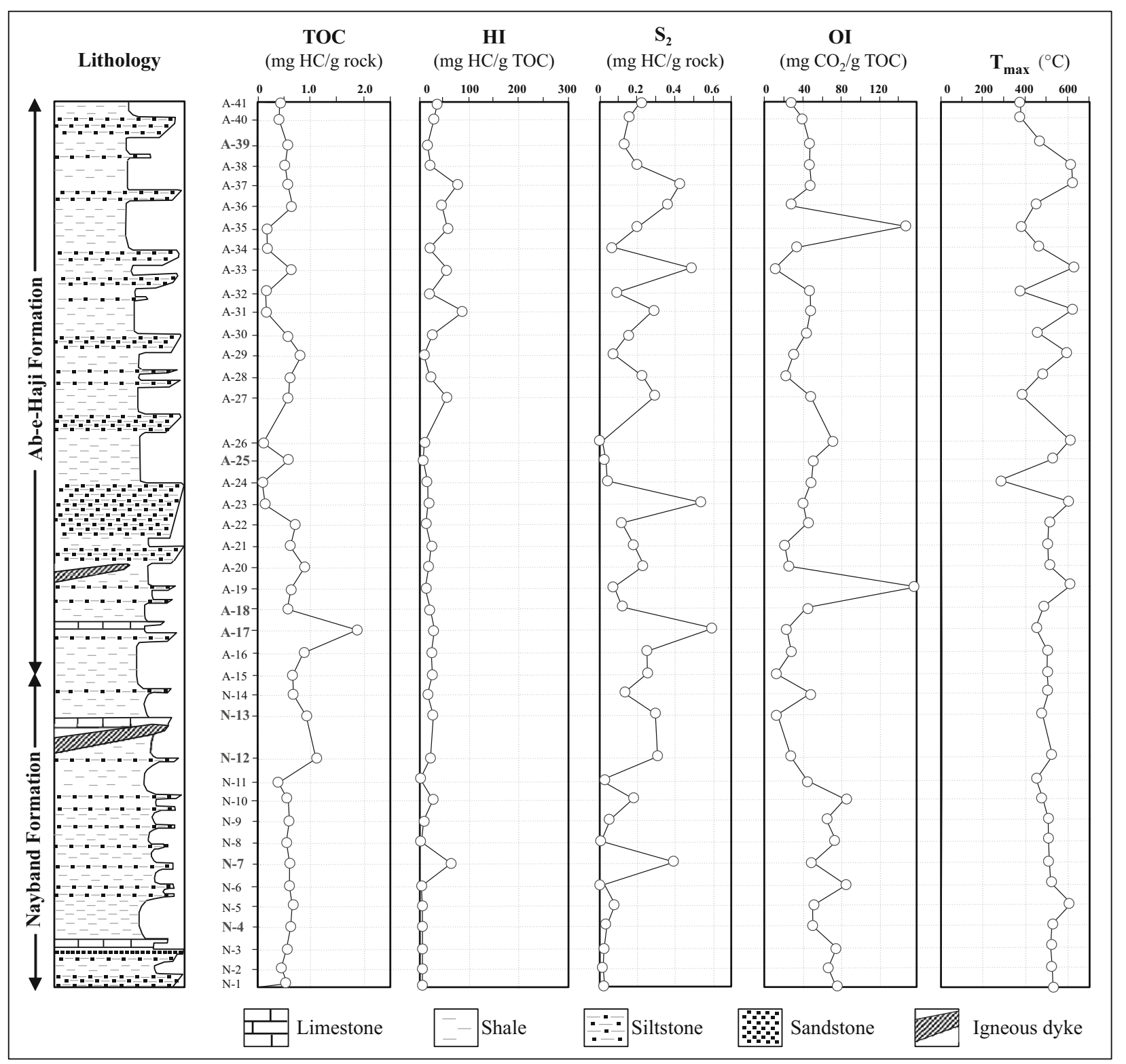

Fig. 4 Geochemical log based on Rock-Eval pyrolysis data for the studied formations at Kamarmacheh Kuh Section. Samples selected for organic petrographic analyses are highlighted in boldface (see Table 2)

aliquots were loaded into crucibles and analyzed following the standard guidelines (Espitalié et al. 1977).

Representative samples were selected from each of the studied formations for petrographic evaluations. For this, crushed aliquots of the samples were mounted in epoxy resin, ground and polished for microscopic studies. A computerized Zeiss Axioplan (II) photomicroscope equipped with a J\&M photomultiplier calibrated with standards of known reflectance $(0.431 \%$ to $5.35 \%)$ was used for organic petrographic analyses. Observations were made using standard guidelines (Stach et al. 1982; Taylor et al.
1998) under reflected light using a 100X oil immersed objective.

\section{Results}

\subsection{Rock-Eval pyrolysis}

Rock-Eval parameters obtained from pyrolysis of Nayband and Ab-e-Haji samples (Table 1) indicate minor potential for generation of hydrocarbons from the associated organic 
Table 2 List of samples selected for organic petrographic analyses from the studied formations

\begin{tabular}{llllll}
\hline Formation & Sample & Mean $\mathrm{VR}_{\mathrm{o}}(\%)$ & Standard deviation & Number of readings & VR $\mathrm{o}_{\mathrm{o}}$ range $(\%)$ \\
\hline Ab-e-Haji & $\mathrm{A}-39$ & 1.12 & 0.38 & 100 & $0.35-0.88$ \\
& $\mathrm{~A}-25$ & 0.80 & 0.22 & 37 & $0.35-1.20$ \\
& $\mathrm{~A}-18$ & 0.83 & 0.16 & 95 & $0.55-1.00$ \\
& $\mathrm{~A}-17$ & 0.71 & 0.33 & 39 & $0.31-1.12$ \\
Nayband & $\mathrm{N}-13$ & 1.02 & 0.27 & 33 & $0.52-1.27$ \\
& $\mathrm{~N}-12$ & 0.96 & 0.20 & 38 & $0.62-1.27$ \\
& $\mathrm{~N}-7$ & 0.88 & 0.18 & 11 & $0.52-1.22$ \\
& $\mathrm{~N}-4$ & 0.97 & 0.21 & & $0.62-1.22$ \\
\hline
\end{tabular}

matter (Fig. 3). This is consistent with previous findings about the quality of organic matter preserved in the studied formations (Alizadeh et al. 2011; Yousefi and Behbahani 2017; Zamansani et al. 2019).

According to the obtained geochemical results, the organic matter contained within the Nayband formation is of terrestrial origin and has low hydrogen contents (e.g., HI values mostly below $70 \mathrm{mg} \mathrm{HC} / \mathrm{g}$ TOC) (Fig. 3). This indicates that the organic matter suffered major oxidation during transport and/or sedimentation. Similarly, samples from the Ab-e-Haji Formation are consistent with predominantly hydrogen-poor terrestrial organic matter that was deposited under oxic conditions (Figs. 3, 4). The very low HI values (mostly below $100 \mathrm{mg} \mathrm{HC} / \mathrm{g}$ TOC) along with very low $\mathrm{S}_{2}$ readings (mostly below $1 \mathrm{mg} \mathrm{HC/g}$ rock) indicate that a major fraction of the associated TOC in both formations is inert and will not participate in the process of hydrocarbon generation (Table 1). Therefore, it can be concluded that the majority of the studied samples from Nayband and Ab-e-Haji formations are characterized as poor to fair source rocks with minor potential for hydrocarbon generation (Figs. 3, 4).

In terms of thermal maturity, the obtained $T_{\max }$ values should be used with caution. Owing to very low $S_{2}$ readings for our samples, $T_{\max }$ values cannot provide an accurate measure of maturity. This is supported by the wide ranges of variation observed for the $T_{\max }$ readings (Fig. 4). Therefore, we rely upon vitrinite reflectance measurements for maturity evaluation of the studied formations.
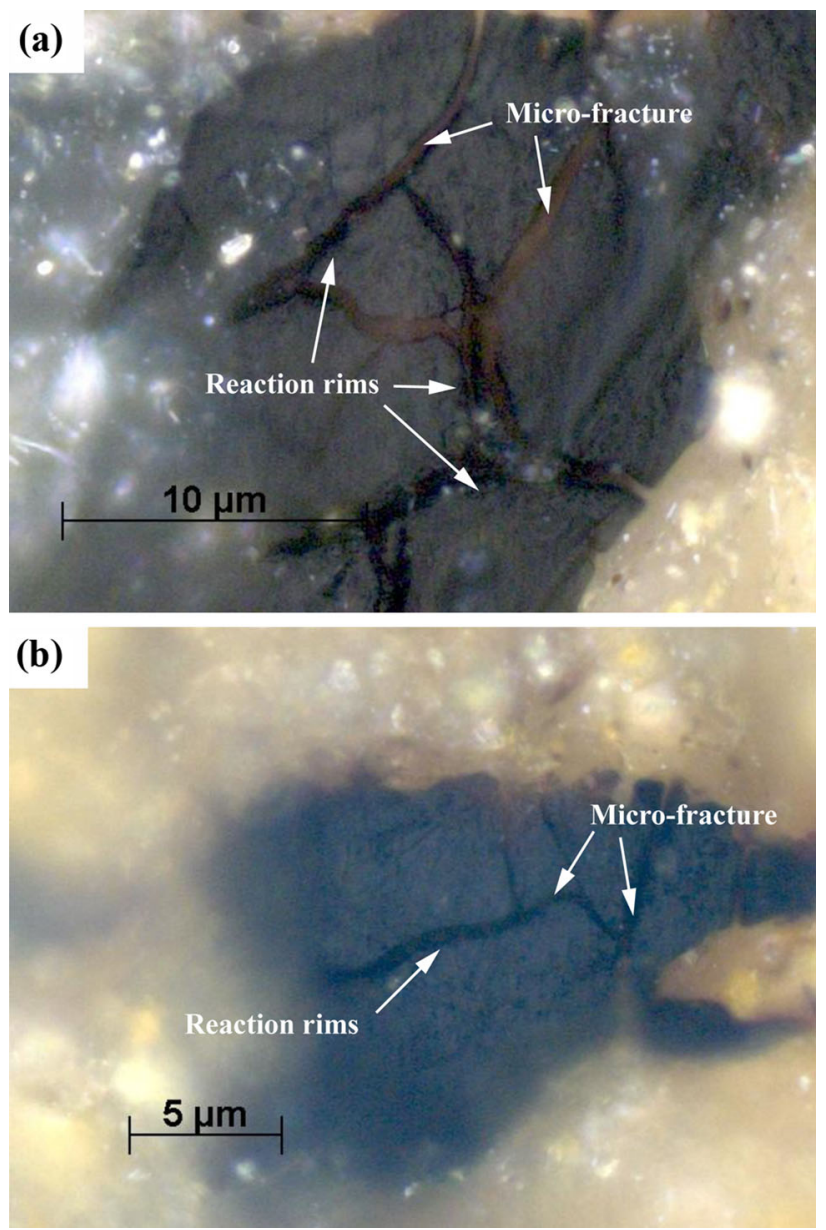

Fig. 5 Photomicrographs of samples from the lower parts of the Nayband Formation. Samples N-4 a and N-7 b contain vitrinite particles with microfractures and dark reaction rims (see Fig. 4 for stratigrpahic locations of these samples) 

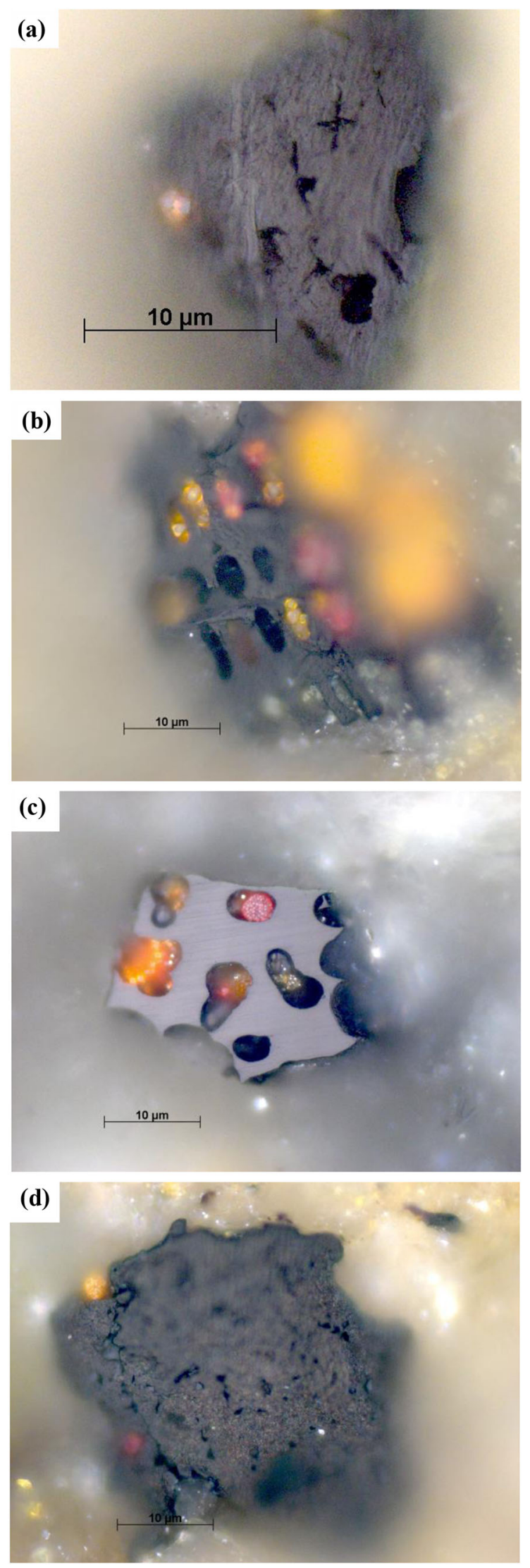

4Fig. 6 Photomicrographs of Nayband Formation samples N-12 (a, b) and N-13 (c, d) (see Fig. 4 for stratigrpahic locations of these samples)

\subsection{Organic petrography}

Representative samples were selected from Nayband and Ab-e-Haji formations for detailed organic petrographic inspections and for vitrinite reflectance measurements (Table 2). Our criteria for selecting these samples were based on (i) visual examination of their colors in the hand specimen, and (ii) geochemical screening based on TOC readings from Rock-Eval pyrolysis (Table 1 and Fig. 4). Generally, samples with higher TOC and darker colors were preferentially selected for petrographic analyses (Table 2).

In line with previous studies (Yousefi and Behbahani 2017), vitrinite reflectance readings obtained from organic petrography indicate that the studied formations are thermally mature (Table 2). In addition, organic petrographic inspections provided more robust assessment of the maceral constitution of studied samples. This technique was used in combination with bulk-rock pyrolysis data to better understand the variations of organic matter type among the studied formations. Our results indicate that the samples from lower parts of the Nayband Formation (i.e. samples $\mathrm{N}-4$ and N-7) are rich in vitrinite and inertinite macerals (Fig. 5). In addition, vitrinite macerals in these samples are mostly characterized with micro-fractures and dark oxidation rims. These observations are strong indications for the natural oxidation during transport and/or sedimentation of the organic matter (Lo and Cardott 1995). These interpretations are further supported by the Rock-Eval pyrolysis results mentioned above.

Moving up within the Nayband Formation (i.e. samples $\mathrm{N}-12$ and $\mathrm{N}-13$ ), the relative abundance of semifusinite macerals increases (Fig. 6a, b). In addition, a similar increase in the relative abundance of combustion chars is conspicuous towards the top of the Nayband Formation (Fig. 6c, d).

In a similar fashion, semifusinite and combustion chars are predominant in the lowermost samples of the Ab-e-Haji Formation (i.e. samples A-17 and A-18, Fig. 7).

However, the relative abundance of semifusinite and combustion chars decreases rapidly towards the top of the Ab-e-Haji Formation (i.e. samples A-25 and A-39). Vitrinites with marked weathering characteristics Once again become the dominant maceral type in the upper parts of the Ab-e-Haji Formation (Fig. 8). It is noteworthy that weathering features are relatively stronger in the Ab-e-Haji samples compared to those observed in the basal parts of the Nayband Formation (Fig. 8). 

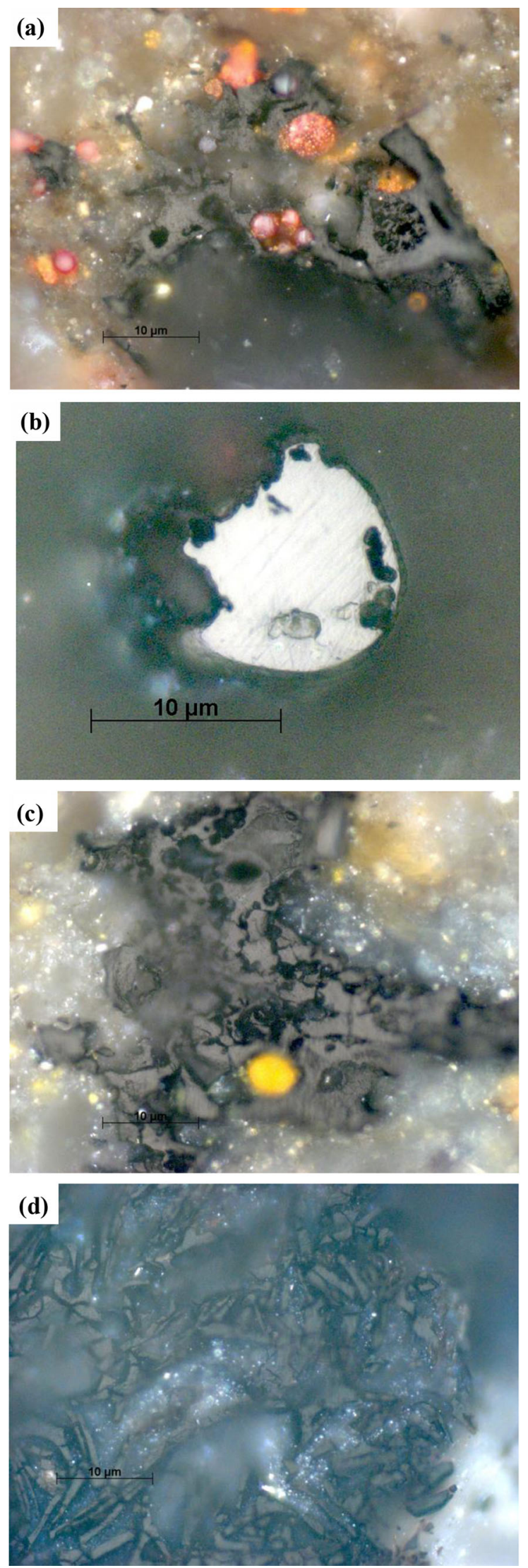

4Fig. 7 Photomicrographs of the Ab-e-Haji Formation samples A-17 a, b and A-18 c, d, showing the predominance of semifusinite macerals and combustion chars (see Fig. 4 for stratigrpahic locations of these samples)

\section{Discussion and paleo-environmental interpretation}

Several lines of evidence corroborate the occurrence of wildfire events at the T-J boundary of Central Iran. In the aftermath of Eo-Cimmerian event, a large retrograding sedimentary sequence started across most of the Central Iranian Micro-continent (Fig. 9a, b). The originally marine conditions during deposition of the Nayband Formation gradually transformed into fluvial/continental environments during deposition of the Ab-e-Haji Formation. Organic petrographic results obtained in this study are consistent with an increase in the concentration of semifusinite and combustion chars around the T-J boundary (Figs. 6, 7). Similar observations have been interpreted by other researchers as evidence for wildfire events in various sedimentary basins around the world (Collinson et al. 2007; Hudspith et al. 2012). Therefore, we suggest that widespread wildfire events could have occurred during the T-J boundary in the Central Iranian basin (Fig. 9b).

It is well known that wildfire events can remove the vegetation cover and increase the surface water run-off, which in turn, would affect sedimentation in the adjacent depositional environments (Nichols and Jones 1992). The Late Triassic sediments of the Nayband Formation are composed of highly fossiliferous marine carbonates and shallow-marine siliciclastic sediments containing coal inter-layers (Fürsich et al. 2005a). In contrast, the Lower Jurassic Ab-e-Haji Formation consists of recycled fluviodeltaic sediments deposited under humid conditions with short transport distances (Salehi et al. 2014; Shadan and Hosseini-Barzi 2013). Provenance studies on sandstones of the Ab-e-Haji Formation have indicated that these sediments were formed by recycling of older sedimentary rocks (Salehi et al. 2014; Shadan and Hosseini-Barzi 2013). Such conditions could have been met following a major wildfire event, which could potentially remove the vegetation cover and expose older sedimentary units (including the Nayband Formation) (Fig. 9b). Additionally, the enhanced erosion and increased sediment supply into nearby depocenters would explain the exceptionally large thickness of sediments accumulated in the Jurassic system (e.g., Fürsich et al. 2005b). This model can also explain petrographic observations including the predominance of 

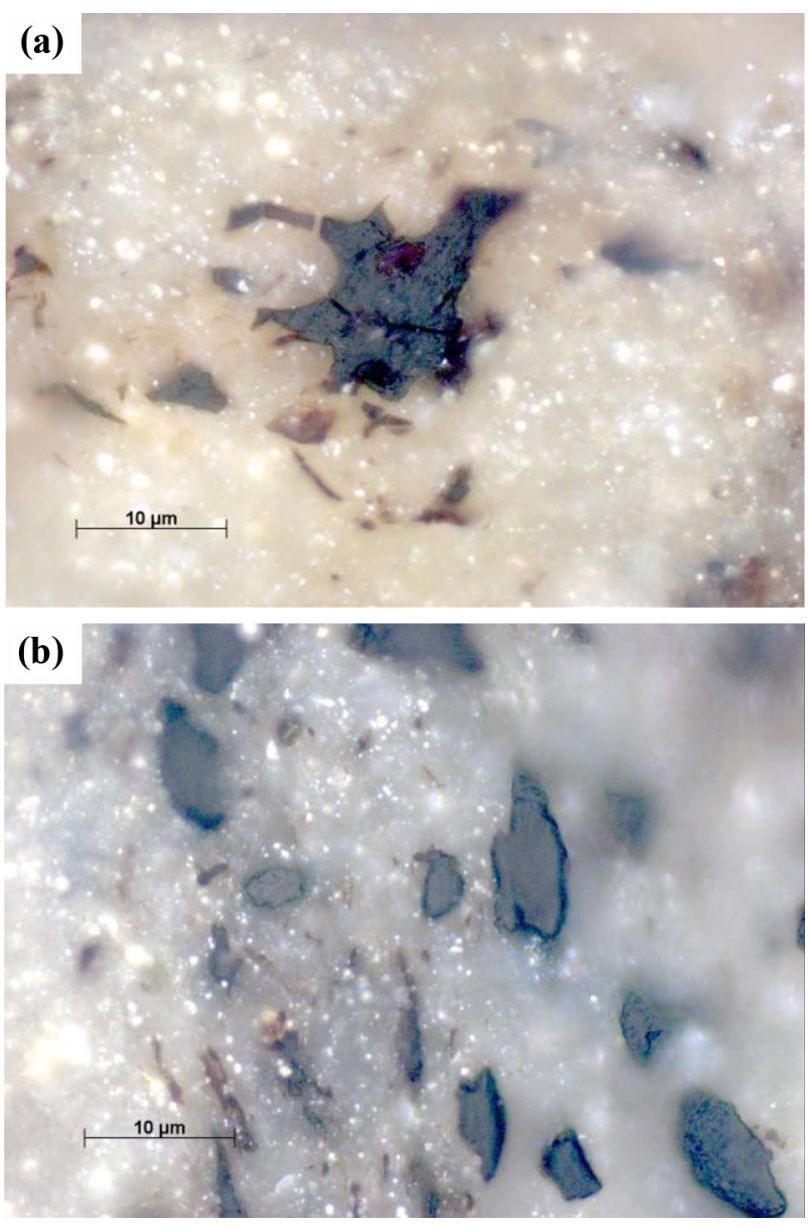

Fig. 8 Photomicrographs of samples from the Ab-e-Haji Formation showing reworked fusinite particles in sample A-25 a and reworked vitrinite particles in sample A-39 b (see Fig. 4 for stratigrpahic locations of these samples) reworked organic matter in the Ab-e-Haji Formation. These organic constituents have likely experienced multiple cycles of transportation under oxic conditions. These factors could have resulted in considerable loss of hydrocarbon generation potential for the studied sediments, which is also supported by the Rock-Eval pyrolysis results (Fig. 3).

\section{Conclusions}

Results from organic geochemical and petrographical analyses of a suit of samples from an Upper TriassicLower Jurassic sedimentary succession from Central Iran provides evidence for wildfire events at $\mathrm{T}-\mathrm{J}$ boundary. The removal of vegetation cover exposed the older sedimentary units for enhanced erosion. Subsequently, a large thickness of recycled sediments were accumulated in the nearby depocenters. The organic matter contained in these sediments underwent intensive oxidation and therefore has negligible hydrocarbon generation potential. Additional evidence for widespread wildfire events could come from detailed PAH analysis of the extractable organic material and plant fossil studies across the $T-J$ boundary. 


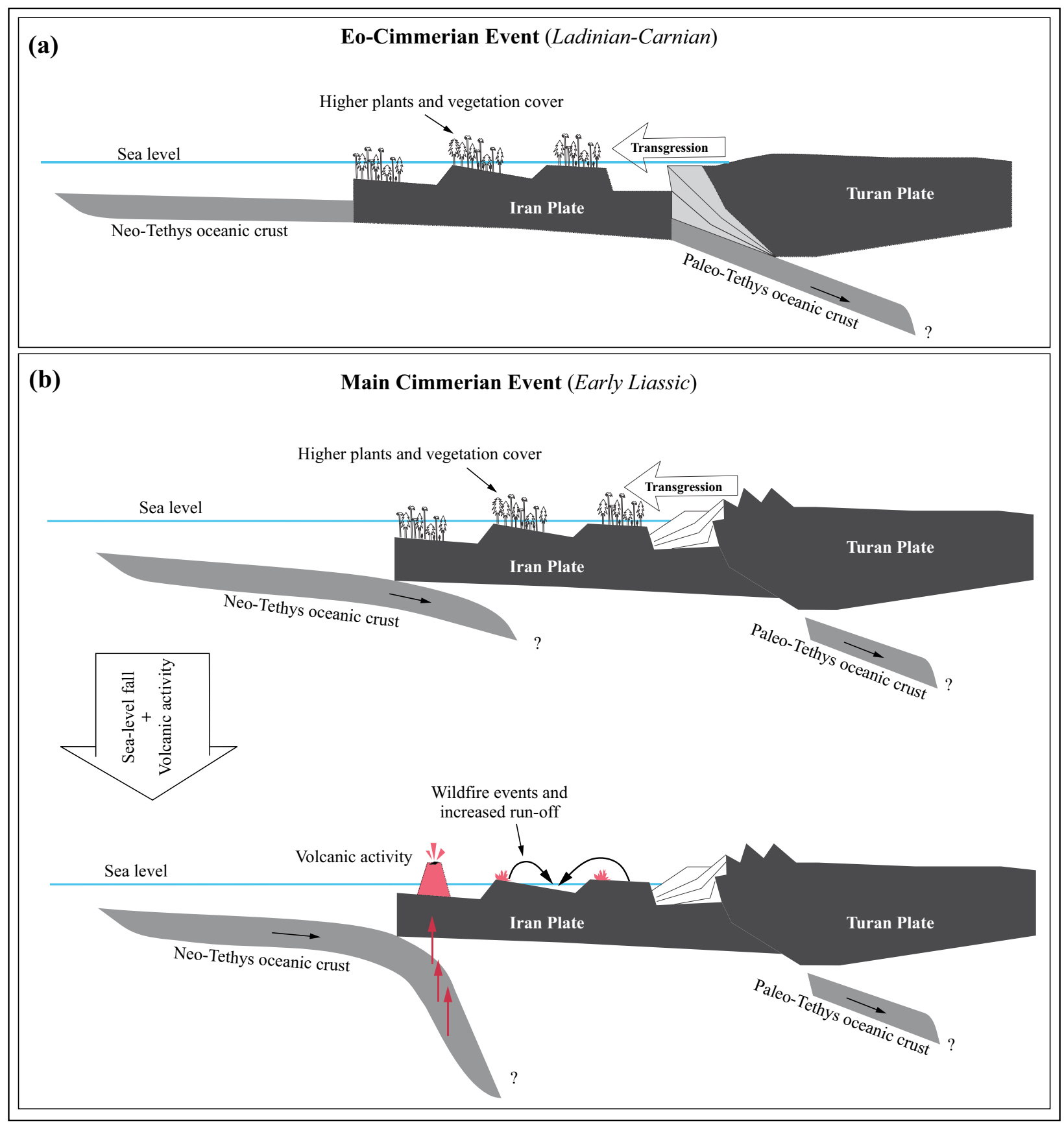

Fig. 9 Paleo-geographic settings of Central Iran during the Eo-Cimmerian event a and during the Main Cimmerian Event $\mathbf{b}$ (with modifications from Wilmsen et al. 2009b)

Acknowledgements The authors would like to express their sincere thanks to the exploration directorate of NIOC for providing the data and to the Petroleum Geology and Geochemistry Research Center (PGGRC) at Shahid Chamran University of Ahvaz for providing laboratory services. We also wish to extend our thanks to Professor B.J. Cardott for his helpful comments on the organic petrography of the samples.

Authors' contributions All authors agree they have read and approved the manuscript.
Funding The exploration directorate of NIOC provided the data. The Petroleum Geology and Geochemistry Research Center (PGGRC) at Shahid Chamran University of Ahvaz provided laboratory services for conducting organic petrographic studies.

\section{Data availability Yes.}

\section{Declaration}

Conflict of interest The authors declare that they have no conflict of interest. 
Open Access This article is licensed under a Creative Commons Attribution 4.0 International License, which permits use, sharing, adaptation, distribution and reproduction in any medium or format, as long as you give appropriate credit to the original author(s) and the source, provide a link to the Creative Commons licence, and indicate if changes were made. The images or other third party material in this article are included in the article's Creative Commons licence, unless indicated otherwise in a credit line to the material. If material is not included in the article's Creative Commons licence and your intended use is not permitted by statutory regulation or exceeds the permitted use, you will need to obtain permission directly from the copyright holder. To view a copy of this licence, visit http://creativecommons. org/licenses/by/4.0/.

\section{References}

Alizadeh B, Alipour M, Hosseini SH, Jahangard AA (2010) Geochemical characteristics of Triassic-Jurassic boundary in Tabas Basin, Central Iran Paper presented at the 63rd Geological Congress of Turkey, Turkey, 5-9 April

Alizadeh B, Alipour M, Hosseini SH, Jahangard AA (2011) Paleoenvironmental reconstruction using biological markers for the Upper Triassic-Middle Jurassic sedimentary succession in Tabas Basin, central Iran. Org Geochem 42:431-437

Berberian M, King G (1981) Towards a paleogeography and tectonic evolution of Iran. Can J Earth Sci 18:210-265

Collinson ME, Steart D, Scott A, Glasspool I, Hooker J (2007) Episodic fire, runoff and deposition at the Palaeocene-Eocene boundary. J Geol Soc 164:87-97

Espitalié J, Laporte JL, Madec M, Marquis F, Leplat P, Paulet J, Boutefeu A (1977) Méthode rapide de caractérisation des roches mètres, de leur potentiel pétrolier et de leur degré d'évolution. Oil Gas Sci Technol 32:23-42

Fürsich F, Hautmann M, Senowbari-Daryan B, Seyed-Emami K (2005a) The Upper Triassic Nayband and Darkuh formations of east-central Iran: Stratigraphy, facies patterns and biota of extensional basins on an accreted terrane. Beringeria 35:53-133

Fürsich FT, Wilmsen M, Seyed-Emami K, Cecca F, Majidifard MR (2005b) The upper Shemshak Formation (Toarcian-Aalenian) of the Eastern Alborz (Iran): Biota and palaeoenvironments during a transgressive-regressive cycle. Facies 51:365-384

Fürsich FT, Wilmsen M, Seyed-Emami K, Majidifard MR (2009) Lithostratigraphy of the Upper Triassic-Middle Jurassic Shemshak Group of Northern Iran. Geol Soc Lond Spec Publ 312:129-160

Hassanzadeh J, Wernicke BP (2016) The Neotethyan Sanandaj-Sirjan zone of Iran as an archetype for passive margin-arc transitions. Tectonics 35:586-621

Hudspith V, Scott A, Collinson M, Pronina N, Beeley T (2012) Evaluating the extent to which wildfire history can be interpreted from inertinite distribution in coal pillars: an example from the Late Permian, Kuznetsk Basin, Russia. Int J Coal Geol 89:13-25

Jiang C, Alexander R, Kagi RI, Murray AP (1998) Polycyclic aromatic hydrocarbons in ancient sediments and their relationships to palaeoclimate. Org Geochem 29:1721-1735
Jones TP, Ash S, Figueiral I (2002) Late Triassic charcoal from Petrified Forest National Park, Arizona, USA. Palaeogeogr Palaeoclimatol Palaeoecol 188:127-139

Korkmaz S, Gülbay RK (2007) Organic geochemical characteristics and depositional environments of the Jurassic coals in the eastern Taurus of Southern Turkey. Int J Coal Geol 70:292-304

Lo H, Cardott B (1995) Detection of natural weathering of Upper McAlester coal and Woodford Shale, Oklahoma, USA. Org Geochem 22:73-83

Marynowski L, Simoneit BR (2009) Widespread Upper Triassic to Lower Jurassic wildfire records from Poland: evidence from charcoal and pyrolytic polycyclic aromatic hydrocarbons. Palaios 24:785-798

Nichols G, Jones T (1992) Fusain in Carboniferous shallow marine sediments, Donegal, Ireland: the sedimentological effects of wildfire. Sedimentology 39:487-502

Salehi MA, Moussavi-Harami SR, Mahboubi A, Wilmsen M, Heubeck C (2014) Tectonic and palaeogeographic implications of compositional variations within the siliciclastic Ab-Haji Formation (Lower Jurassic, east-central Iran). Neues Jahrbuch Für Geologie Und Paläontologie-Abhandlungen 271:21-48

Seyed-Emami K (2003) Triassic in Iran. Facies 48:91-106

Seyed-Emami K, Fursich F, Wilmsen M (2004) Documentation and significance of tectonic events in the northern Tabas Block (eastcentral Iran) during the Middle and Late Jurassic Rivista Italiana di Paleontologia e Stratigrafia

Shadan M, Hosseini-Barzi M (2013) Petrography and geochemistry of the Ab-e-Haji Formation in central Iran: implications for provenance and tectonic setting in the southern part of the Tabas block. Revista Mexicana De Ciencias Geológicas 30:80-95

Stach E, Mackowsky MT, Teichmuller M, Taylor G, Chandra D, Teichmuller R (1982) Stach's textbook of coal petrology. Gebruder, Borntraeger, Berlin

Stöcklin J (1974) Possible ancient continental margins in Iran. In: Burk CA, Drake CL (eds) The geology of continental margins. Springer, pp 873-887

Stöcklin J, Eftekhar-Nezhad J, Hushmand-Zadeh A (1965) Geology of the Shotori range (Tabas area, east Iran), vol 3. Geological Survey of Iran

Taylor GH, Teichmüller M, Davis A, Diessel C, Littke R, Robert P (1998) Organic petrology. Gebruder Borntraeger

Wilmsen M, Fürsich FT, Seyed-Emami K, Majidifard MR (2009a) An overview of the stratigraphy and facies development of the Jurassic System on the Tabas Block, east-central Iran. Geol Soc Lond Spec Publ 312:323-343

Wilmsen M, Fürsich FT, Seyed-Emami K, Majidifard MR, Taheri J (2009b) The Cimmerian Orogeny in northern Iran: Tectonostratigraphic evidence from the foreland. Terra Nova 21:211-218

Yousefi M, Behbahani R (2017) Organic geochemistry of the Late Triassic Nayband Formation at the Parvadeh Area, Tabas, EastCentral Iran. Appl Sedimentol 4:22-41

Zamansani N, Rajabzadeh MA, Littke R, Zieger L, Baniasad A (2019) Organic petrology and geochemistry of Triassic and Jurassic coals of the Tabas Basin, Northeastern/Central Iran. Int J Coal Sci Technol 6:354-371 